\title{
ESOPHAGEAL VARICES:
}

\section{MAJOR ENDOSCOPIC FINDING ON UPPER GI ENDOSCOPY}

\author{
*DR. MOAZZAM ALI ATIF \\ Rahim Yar Khan \\ DR IRFAN AHMAD \\ Rahim Yar Khan
}

Accepted for publication: 22/08/2008

\begin{abstract}
Objectives To document the frequency of esophageal varices and their importance in a tertiary care hospital of Southern Punjab. Design: Observational. Setting: Endoscopy unit of Sheikh Zayed Medical College/Hospital. Period: From Nov 2005 to May 2007. Materials \& Methods The data of 500 patients who underwent upper Gl endoscopy was analyzed. Demographic features, reasons for referral and endoscopic diagnoses were noted. Results: Among 500 patients, $57 \%$ were referred due to upper $\mathrm{GI}$ bleeding, $9 \%$ due to dysphagia, $8 \%$ due to persistent vomiting and $7 \%$ due to dyspeptic symptoms. Common endoscopic diagnoses were esophageal varices (44\%). Conclusion: Major Endoscopic finding in our study was esophageal varices. Gastric or duodenal ulcers, congestive gastropathy, obstructive lesions of esophagus and stomach were the next most common observations.
\end{abstract}

Key words: $\quad$ Upper GI Endoscopy, esophageal varices.

\section{INTRODUCTION}

Upper Gastrointestinal (UGI) complaints are very common, both in indoor and outdoor patients. Patients may present primarily for UGI symptoms or have these along with other diseases. Sometimes, they create great diagnostic difficulty. In many centers, UGI Endoscopy has more become the initial and usually sole diagnostic approach to unexplained UGI symptoms ${ }^{1}$.

History of UGI Endoscopy dates back to 1868 when Kussmaul designed first rigid UGI endoscope, followed by semi flexible endoscope by Rudolf Schindler in 1932 and first flexible fiber optic gastro scope in 1957 by Hirschowirtz ${ }^{2}$. The emergence of forward viewing fiber optic pan endoscope prompted studies aimed at comparing the diagnostic results of EGD with those of conventional contrast fluoroscopy and radiography.

UGI bleeding is a global problem and common medical emergency ${ }^{2}$. The causes of bleeding vary from country to country. Commonest causes being peptic ulcer, gastric erosions, esophageal varices and mucosal tears ${ }^{3,4,5,6}$.

UGI Endoscopy is the diagnostic modality of choice for UGI bleeding ${ }^{8}$. Patients usually present with hematemesis, melaena or hematochezia ${ }^{4,7}$. In addition to bleeding, obstructive lesions like CA esophagus or stomach, strictures of esophagus, hiatal hernias and gastropathies are also common endoscopic findings. 
In this study, we have tried to find out the frequency of esophageal varices in our patients and highlight its importance in the region of Southern Punjab.

\section{MATERIALS AND METHODS}

This observational study was conducted at Medical Unit I of SZMC/SZH, Rahim Yar Khan over a period of one and half year from November 2005 to May 2007. Patients were referred from inpatient, outpatient and accident \& emergency departments.

A written informed consent was taken from every patient before the procedure. Olympus GIP type E3 gastroscope was used and all procedures were done by a single operator (I.A.). Local anesthetic, $4 \%$ xylocaine solution, was used for gargles before the procedures. Midazolam IV was given to anxious non-cirrhotic patients. For obliteration of esophageal varices, $70 \%$ alcohol was used as sclerosant agent and band ligation was done with Saeed Six Shooter multiple band ligator.

Parameters recorded were age and sex of the patients, indications for endoscopy, endoscopic diagnoses, and the types of therapeutic intervention.

The data was entered in SPSS 10 software. The quantitative data was recorded as mean and standard deviation and qualitative data as percentage.

\section{RESULTS}

Of 500 patients undergone upper GI endoscopy, 316(63 $\%)$ were male and $184(37 \%)$ were female. The mean age of the patients was $42.45 \pm 16.52$ years. The patients were mainly between 30 and 50 years of age. Two hundred and sixty five patients were referred from Inpatient departments, 196 from Outpatient and 39 from Accident and Emergency departments. The common indications for endoscopy are shown in Table I. Other indications were iron deficiency anemia in 13(2.6\%) patients, pain epigastrium in $9(1.8 \%)$, chronic diarrhea in $6(1.2 \%)$, weight loss in 5(1.0\%), odynophagia in 2(0.4\%), hematochezia in $1(0.2 \%)$, anorexia in $1(0.2 \%)$ and atypical chest pain in $1(0.2 \%)$ patient.

\begin{tabular}{|l|c|c|}
\hline \multicolumn{3}{|c|}{ Table-I. Common indications for UGI endoscopy } \\
\hline Indications & No of pts & $\%$ age \\
\hline UGI bleed & 287 & $57.4 \%$ \\
\hline Dysphagia & 46 & $9.2 \%$ \\
\hline Persistent vomiting & 39 & $7.8 \%$ \\
\hline Dyspepsia & 35 & $7 \%$ \\
\hline Followup sclrotherapy or band ligation & 31 & $6.2 \%$ \\
\hline Surveillance for esophageal varices & 24 & $4.8 \%$ \\
\hline
\end{tabular}

The common endoscopic diagnoses are shown in Table II.

\section{Table-Il. Common endoscopic diagnoses}

\begin{tabular}{|l|c|c|}
\hline \multicolumn{1}{|c|}{ Diagnosis } & No. of pts & $\%$ age \\
\hline Esophageal varices & 218 & $43.6 \%$ \\
\hline Normal & 82 & $16.4 \%$ \\
\hline Gastroesophageal reflux disease & 47 & $9.4 \%$ \\
\hline Gastritis & 21 & $4.2 \%$ \\
\hline Gastric ulcer & 20 & $4 \%$ \\
\hline Esophageal carcinoma & 14 & $2.8 \%$ \\
\hline NSAID induced gastropathy & 13 & $2.6 \%$ \\
\hline Mallory weiss tear & 12 & $2.4 \%$ \\
\hline Benign esophageal stricture & 12 & $2.4 \%$ \\
\hline Duodenal ulcer & 12 & $2.4 \%$ \\
\hline
\end{tabular}

Other diagnoses were esophageal ulcer in 10(2.0\%) patients, carcinoma stomach in $7(1.4 \%)$, portal hypertensive gastropathy in $6(1.2 \%)$, carcinoma duodenum in $5(1.0 \%)$, achalasia in $5(1.0 \%)$, pyloric stenosis in $4(0.8 \%)$, extrinsic pyloric compression in $3(0.6 \%)$, celiac disease in $3(0.6 \%)$, fundal varices in $2(0.4 \%)$, esophageal candidiasis in $2(0.4 \%)$, bleeding diathesis in $1(0.2 \%)$ and carcinoma pharynx in $1(0.2 \%)$ patient. 
The endoscopic procedure was diagnostic in 316(63.2\%) patients and therapeutic intervention was carried out in 184(36.8 \%) patients. Therapeutic procedures included sclerotherapy in $97(19.4 \%)$ and endoscopic variceal band ligation in $87(17.4 \%)$ patients.

\section{DISCUSSION}

This study revealed that our results were somewhat different from various studies conducted in western countries but comparable with studies conducted in Pakistan. Most of endoscopic examinations were well tolerated and were performed with only slight sedation. Sedation and information should be offered to all patients undergoing Endoscopy ${ }^{9}$. At present days, endoscopy offers a direct picture of the whole stomach and enables close observation of details. Any change found can be photographed in natural colors. An early Endoscopy in cases of UGI bleeding has considerably altered the older concept of the causes of bleeding but the consequences of the event have remained the same.

Age and sex ratio in the study under discussion was similar to those of other reported studies ${ }^{10}$. In the National American Society for Gastrointestinal Endoscopic Bleeding Survey (ASGE) on UGI tract involving 2,225 patients, 6 pathological entities were responsible for most bleeding episodes ${ }^{11,12}$. These include duodenal and gastric ulcer, acute gastritis, esophageal varices, esophagitis and Mallory Weis syndrome. In this study esophageal varices were the most common cause followed by superficial mucosal lesion like gastric erosions and congestive gastropathy, and then peptic ulcer. These results were different form studies conducted in Western countries. In the ASGE Bleeding Survey, peptic ulcer was the most common cause, varices were present in $15.4 \%$ case compared with $46 \%$ in our study ${ }^{11,12}$. Similar data was observed in $\mathrm{UK}^{13}$.

But our results are comparable with the results of studies from other developing countries e.g., in a study conducted in Kenya at National Hospital esophageal varices was major cause of UGI bleeding. These results are also comparable with studies conducted in Pakistan $14,15,16,17,18,19,20$. The results of this study were almost similar to a study conducted at Mayo Hospital to know the cause of upper $\mathrm{GI}$ bleed $^{21,22}$. The higher incidence of oesophageal varices was due to the high rate of chronic infection with Hepatitis $B$ virus (HBV) and Hepatitis $\mathrm{C}$ virus (HCV) leading to end stage liver disease (cirrhosis).

Superficial mucosal lesion was recognized as the second commonest finding in this study. Incidence of ulcers is much less as compared to Western studies as already mentioned ${ }^{11,12,13}$. Duodenal ulcers are more common as compared to gastric ulcer in our study as seen in some other local studies ${ }^{14}$. Lower incidence of peptic ulcer as a cause of bleeding could be due to frequent use of acid suppressing drugs by medical practitioners in patients with symptoms of dyspepsia. Alcohol consumption appeared to play little role as a cause of UGI bleeding in this population, most likely due to religious prohibition of alcohol use in the country. Tumors of upper GI tract are less common in our study, but similar data is shown by local studies ${ }^{16}$. 18 patients had normal endoscopic findings, majority of them being females $(12.2 \%)$.

\section{CONCLUSION}

Upper GI endoscopy is the only reliable tool for correctly determining the etiology of upper $\mathrm{Gl}$ complaints. Esophageal varices form the major bulk of endoscopic findings reflecting high prevalence of chronic liver disease which, unfortunately, is much higher in Southern Punjab. Esophageal varices are real problem within our area but the scope has changed in the western world. Variations in disease pattern from time to time require the periodic studies to be aware of the current underlying mechanism of the ailments in the area of work. Total reliance on literature may consume local resources.

\section{REFERENCES}

1. Bernard M Schuman, UGI endoscopy, In: Hambrich WS, Schaffner F, Berk JE. Bockus Gastroenterology, $5^{\text {th }}$ ed, 
New York: WB Saunders, 295-303.

2. Bilal A, Nagra H, Shahid M. Upper GIT bleed; Prevalence of peptic ulcer. The Prof Med J Oct-Dec 2004; 11:400-05.

3. Palmer KR, Penman ID. Diseases of the alimentary tract and pancreas. In Haslett $C$, Chilvers ER, Hunter JAA, Boon NA. Davidson's principles and practice of medicine. $19^{\text {th }}$ ed. Edinburgh: Churchill living stone, 2002: 747-830.

4. Longstrath GM, Zuckerman GR, Rockey DC. Successful out patient management of acute upper gastrointestinal haemorrhage, use of practice guidelines in a long patient series. Gastro intes Endos 1998; 47: 219.

5. Clark ML, Kumar PJ, Gastroenterology. In: Kumar P, Clark ML, editors. Clinical medicine $4^{\text {th }}$ de. Edinburg: WB Saunders, 1998: 217-87.

6. Farooqi JL, Farooqi, RJ. Endoscopic management of bleeding peptic ulcer. J coll AAphysicians surg Pakistan 2001; 11: 530-34.

7. McQuaid KR, Alimentary tract. In Tierney LM, Mcphee SI, Papadakis MA, editors. Current medical diagnosis and treatment, $45^{\text {th }}$ ed. New York: McGraw hill 2006: 573-75.

8. Iqbal J. Upper gastrointestinal bleeding; assessment of causes and comparison with other relevant studies. The Prof Med J Oct-Dec 2004; 11:400-05.

9. Probert CS, Jayanthi V, Quinn J, Marberry JF. Information requirements and sedation preferences of patients undergoing endoscopy of the UGI tract. Endoscopy. 1991 Jul: 23 (4): 218-9.

10. Qureshi H, Banatwala NN, Sarwar J, Zuberi SJ, Alam. Emergency endoscopy in UGI bleeding. JPMA. Feb 1988; 30-38.

11. Silverstein -EF, Gilbert-DA, Ftedesco-FJ. The national ASGE survey of UGI bleeding. Part II, clinical prognostic factors. Gastrointestinal endoscopy 1981.27: 94-102.

12. Kohlar B, Rieman JF. UGI bleeding values and consequences of emergency endoscopy and endoscopic treatment. Hepatogastroenterol 1991; 38:
198-200.

13. Cormrck MC, Sims TT, Eyre-Brooki. Gastric lesions in portal hypertension inflammatory gastritis or congestive gastropathy gut 1985; 26: 1226 .

14. Khalid Mahmood, Mohammad llyas Saeedi, Riaz Mohammad, Ziaud Din. Upper gastrointestinal Endoscopic findings in patients with dyspepsia $\mathrm{J}$ Postgrad Med Inst Mar 2006;20(1):70-3.

15. Najmul Hassan Shah, Muhammad Sadiq Shah, Ikramullah Khan, Khalid Hameed. An audit of Diagnostic Upper GI Endoscopy and comparison of booked versus open access cases. J Coll Physicians Surg Pak Apr 1999;9(4):174-6

16. Tashfeen Adam, Fatima Javid, Sharbat Khan. Upper Gastrointestinal bleeding: An etiological study of $\mathbf{5 5 2}$ cases. J Pakistan Inst Med Sci Jul 2004;15(1):845-8.

17. Khurram M, Hamama tul Bushra Khaar, Hasan Z, Umar M, Saima Javed, Asghar T et al. A 12 years Audit of Upper Gastrointestinal Endoscopic Procedures. J Coll Physicians Surg Pak Jun 2003;13(6):321-4.

18. Muhammad Khurram, Saima Javed, Hamama tul Bushra Khaar, Fayyaz Goraya, Zubair Hasan. Endoscopic evaluation of 2484 patients with upper GI Hemorrhage. J Rawal Med Coll Dec 2003;7(2):89-91.

19. Waheed AC, Tabassum HM, Anwar AC. Pattern of upper gastrointestinal bleeding at Rahim Yar Khan. Ann King Edward Med Coll Sep 2005;11(3):282-3.

20. Wajahat Hussain Wasty, Mansoor Yousuf, Masoom Raza Mirza. Frequency of Esophageal Varices among patients undergoing GI endoscopy. Pak J Med Sci Jun 2005;21(2):164-7.

21. Iqbal S, Ruknuddin. Liver cirrhosis in north west province of Pakistan. J Coll physicians surg Pakistan; 2002 vol 12(5): 289-291.

22. Alam I, Ahmad H, Najeeb ul haque, Biland B. An upper gastrointestinal endoscopic study of fifty cases of cirrhosis liver. J Postgraduate med inst 1997; 11-5560 . 